\title{
ЧАСТОТА ВЫЯВЛЕНИЯ SARS-CoV-2 В ФЕКАЛИЯХ ДЕТЕЙ \\ С ИНФЕКЦИОННЫМИ ДИАРЕЯМИ В ДЕБЮТЕ ЭПИДЕМИИ COVID-19
}

Н.В.Паркина, Т.А.Коновалова, З.Х.Далелова, Т.А.Кожахметова, С.Б.Яцышина, А.Т.Подколзин

ФБУН ЦНИИ Эпидемиологии Роспотребнадзора, Москва, Россия;

Ключевые слова: COVID-19, дети, инфекционные диареи

\section{THE PREVALENCE OF SARS-CoV-2 IN STOOL SAMPLES FROM CHILDREN WITH DIARRHEAL INFECTIONS IN THE DEBUT OF THE COVID-19 EPIDEMIC IN THE RUSSIAN FEDERATION}

N.V.Parkina, T.A.Konovalova, Z.K.Dalelova, T.A.Kozhakhmetova, S.B.Yatsyshina, A.T.Podkolzin

Central Research Institute for Epidemiology, Moscow, Russia

Key words: COVID-19, children, diarrheal infections

Введение. Вынужденное применение строгих критериев селекции, при определении показаний к обследованию на PHK SARS-CoV-2 в дебюте эпидемического подъема COVID-19, создает риски существенной недооценки числа инфицированных лиц в популяции по данным регистрируемой заболеваемости [1]. Достаточно длительный период выделения SARS-CoV-2 с фекалиями пациентов, в том числе при субманифестном течении COVID-19, которое часто наблюдается у детей, позволяет использовать данный тип материала для выявления скрытой циркуляции SARS-CoV-2 на территориях и оценки объективности регистрируемых уровней заболеваемости [2]. Инфекционные диареи являются наиболее распространенной группой нозологий, надзор за которыми обеспечивает доступность материала для проведения данного мониторинга. Наряду с этим, оценка распространенности SARS-CoV-2 в образцах фекалий позволяет корректнее оценить риски работы с таким материалом в лабораториях, проводящих скрининговую диагностику инфекционных диарей в период пандемии COVID-19 [3].

Цель. Выявление скрытой циркуляции SARS-CoV-2 в дебюте эпидемического подъема заболеваемости COVID-19 на отдельных территориях РФ.

Материалы и методы. В исследование были включены 267 детей с симптомокомплексом инфекционных диарей, обследованных в период с 01.03 .2020 по 12.05 .2020 на территориях Москвы, Московской области, Республики Дагестан, Нижегородской области и Хабаровского края. Выявление PHK SARS-CoV-2 в образцах фекалий проводилось с 
использованием наборов реагентов «РИБО-преп» и «АмплиСенс® Cov-Bat-FL» (ФБУН «ЦНИИ Эпидемиологии») в соответствии с инструкцией производителя. Данные о количестве случаев заболеваний, регистрируемых на включенных в исследование территориях РФ, получены из открытых источников [4].

Результаты. На включенных в исследование территориях, к моменту окончания сбора образцов фекалий от детей с симптомокомплексом инфекционных диарей, регистрировалось от 0 до 115900 зарегистрированных случаев COVID-19. PHK SARSCoV-2 при скрининге образцов фекалий от детей с симптоматикой острых кишечных инфекций (ОКИ) была выявлена только в одном регионе с максимальной зарегистрированной заболеваемостью COVID-19 (таблица).

Таблица. Соотношение результатов тестирования образцов фекалий от пациентов с ОКИ на наличие PHK SARS-CoV-2 с показателями регистрируемой заболеваемости на отдельных территориях

\begin{tabular}{|c|c|c|c|c|}
\hline \multirow[b]{2}{*}{ Регион } & \multicolumn{2}{|c|}{$\begin{array}{lc}\text { Детекция } & \text { PHK } \\
\text { фекS-CoV-2 в } \\
\text { секалия } & \text { детей } \\
\text { симптоматикой ОКИ }\end{array}$} & \multicolumn{2}{|c|}{$\begin{array}{l}\text { Регистрация COVID-19 на } \\
\text { дату окончания сбора } \\
\text { образцов }\end{array}$} \\
\hline & $\begin{array}{l}\text { период } \\
\text { сбора }\end{array}$ & $\begin{array}{l}\text { кол-во } \\
\text { тестированных / } \\
\text { положительных } \\
\text { образцов }\end{array}$ & $\begin{array}{l}\text { кол-во } \\
\text { зарегистрир } \\
\text { ованных } \\
\text { случаев }\end{array}$ & $\begin{array}{l}\text { показатель } \\
\text { заболеваемости } \\
\text { (на } 100 \text { тыс. } \\
\text { населения) }\end{array}$ \\
\hline $\begin{array}{l}\text { Нижегородская } \\
\text { область }\end{array}$ & $\begin{array}{l}11.02 .2020- \\
09.03 .2020\end{array}$ & $30 / 0$ & 0 & 0,00 \\
\hline Республика Дагестан & $\begin{array}{l}13.03 .2020- \\
25.03 .2020\end{array}$ & $52 / 0$ & 0 & 0,00 \\
\hline Хабаровский край & $\begin{array}{l}08.03 .2020- \\
24.03 .2020\end{array}$ & $51 / 0$ & 4 & 0,41 \\
\hline Московская область & $\begin{array}{l}09.03 .2020 \quad- \\
02.04 .2020\end{array}$ & $24 / 0$ & 169 & 2,20 \\
\hline Москва & $\begin{array}{l}30.04 .2020- \\
11.05 .2020\end{array}$ & $110 / 5$ & 115900 & 914,18 \\
\hline
\end{tabular}

Выводы. Тестирование ограниченной выборки образцов фекалий (от 30 до 52 образцов) детей с инфекционными диареями на территориях РФ в период отсутствия официальной регистрации случаев COVID-19, не позволило выявить скрытой циркуляции SARS-CoV-2 в популяции. Для территории Москвы в период регистрируемой заболеваемости COVID- 
19 на уровне 900 на 100 тыс. населения, доля позитивных по содержанию PHK SARSCoV-2 образцов фекалий детей с инфекционными диареями составила 4,5\%.

\section{Литература}

1. World Health Organization. Laboratory testing strategy recommendations for COVID-19 https://apps.who.int/iris/bitstream/handle/10665/331509/WHO-COVID-19-lab_testing2020.1-eng.pdf.

2. Gupta S., Parker J., Smits S., Underwood J., S. Dolwani. Persistent viral shedding of SARSCoV-2 in faeces - a rapid review. Colorectal Dis. 2020 Jun; 22(6):611-620.

DOI: 10.1111/codi.15138. Epub 2020 Jun 4.

3. World Health Organization. Laboratory biosafety guidance related to coronavirus disease (COVID-19):

interim guidance

WHO/WPE/GIH/2020.

https://www.who.int/publications/i/item/laboratory-biosafety-guidance-related-tocoronavirus-disease (COVID-19).

4. COVID-19 pandemic data/Russia medical cases URL: https://en.wikipedia.org/wiki/Template:COVID 19_pandemic_data/Russia_medical_cases (дата обращения 19.08.2020). 